\title{
Investigation of the effects of some phytochemicals on Yersinia ruckeri and antimicrobial resistance
}

\author{
Ş. Önalan ${ }^{a *}$ (D) and M. Çevik ${ }^{a}$ (D) \\ ${ }^{a}$ Van Yuzuncu Yil University, Faculty of Fisheries, Department of Diseases, Van, Turkey \\ *e-mail: sukruonalan@yyu.edu.tr
}

Received: March 10, 2020 - Accepted: June 6, 2020 - Distributed: August 31, 2020

(With 6 figures)

\begin{abstract}
In this study, it is aimed to investigate the effects of Moringa oleifera and Sorbus domestica plant extracts on bacterial disease agents Yersinia ruckeri in aquaculture. Morphological and biochemical properties of 2 different Y. ruckeri isolates were determined. Then, Real-Time PCR analysis and gene sequencing of the isolates were identified. Phytochemicals (M. oleifera and S. domestica) and antibiotics (Oxytetracycline (OX) and Enrofloxacin (ENR)) were used together in the antibiogram test of antibiotics compared to the effect status of antibiotics. Also, the effects of phytochemicals on Y. ruckeri growth was examined comparatively by spectrophotometrically measuring at $600 \mathrm{~nm}$ wavelength every 2 hours according to bacterial growth densities with 10 different groups formed on TSB medium. As a result of the study, it was observed that the isolates formed Gram negative, catalase positive, oxidase negative, mobile and typical Y. ruckeri colonies. After the biochemical tests performed with Microgen ID panel, 99.85\% similarity was determined. The isolates overlap with the 16S rRNA gene region after sequence analysis, and $99 \%$ of the isolates were similar in phylogenetic analysis. After the antibiogram test, Oxytetracycline and Enrofloxacin antibiotics were resistant to Y. ruckeri but the effects of phytochemicals were less on solid medium (MHA). As a result of the measurements carried out in liquid medium (TSB), it was observed that phytochemicals such as $M$. oliefera and $S$. domestica inhibit the growth of bacteria by $40-50 \%$. As the importance of antibiotic resistance is increasing day by day, we believe that these phytochemicals will give positive results in treatment instead of using antibiotics.
\end{abstract}

Keywords: Real-Time PCR, sequencing, antibiogram, fish diseases, phytochemical.

\section{Investigação dos efeitos de alguns fitoquímicos em Yersinia ruckeri e resistência antimicrobiana}

\begin{abstract}
Resumo
Neste estudo, objetiva-se investigar os efeitos dos extratos de plantas de Moringa oleifera e Sorbus domestica sobre agentes bacterianos Yersinia ruckeri na aquicultura. Foram determinadas as propriedades morfológicas e bioquímicas de 2 isolados diferentes de Y. ruckeri. Em seguida, a análise de PCR em tempo real e o seqüenciamento genético dos isolados foram identificados. Fitoquímicos (M. oleifera e $S$. domestica) e antibióticos (Oxitetraciclina e Enrofloxacina) foram usados juntos no teste de antibiograma dos antibióticos em comparação com o status de efeito dos antibióticos. Além disso, os efeitos dos fitoquímicos no crescimento de $Y$. ruckeri foram examinados comparativamente por medição espectrofotométrica no comprimento de onda de $600 \mathrm{~nm}$ a cada 2 horas de acordo com as densidades de crescimento bacteriano com 10 grupos diferentes formados no meio TSB. Como resultado do estudo, observou-se que os isolados formaram colônias Gram-negativas, catalase-positivas, oxidase-negativas, móveis e típicas de Y. ruckeri. Após os testes bioquímicos realizados com o painel Microgen ID, foi determinada uma similaridade de $99,85 \%$. Os isolados se sobrepõem à região do gene 16S rRNA após a análise da sequência e 99\% dos isolados foram semelhantes na análise filogenética. Após o teste do antibiograma, os antibióticos Oxitetraciclina e Enrofloxacina foram resistentes a Y. ruckeri, mas os efeitos dos fitoquímicos foram menores no meio sólido (MHA). Como resultado das medições realizadas em meio líquido (TSB), observou-se que os fitoquímicos inibem o crescimento de bactérias em 40-50\%. Como a importância da resistência aos antibióticos está aumentando dia a dia, acreditamos que as plantas que são mais alternativas e mais adequadas para o uso de antibióticos hoje em dia darão resultados positivos no tratamento.
\end{abstract}

Palavras-chave: Real-Time PCR, sequenciamento, antibiograma, doenças de peixes, fitoquímicos.

\section{Introduction}

Seafood is an important food source with high protein value and necessary for healthy and balanced nutrition. It constitutes $17 \%$ of the animal protein consumed worldwide and $6.5 \%$ of all protein sources (Naylor et al., 2000). In addition to water quality, appropriate environmental conditions, feed supply, marketing and labor problems 
in aquaculture, the most important problem that causes economic losses in aquaculture in freshwater and seas is the existence of various diseases (Timur and Timur, 2003). Economic losses caused by fish diseases and infections are of great importance for the development of the fisheries sector (Pilarski et al., 2008; Ergönül et al., 2012).

Enteric Red Mouth (ERM) created Y. ruckeri seen as intense Turkey and the world. The diseases, which is the most important problem of trout farms, causes serious economic losses. Yersiniozis in all salmonids and catfish, goldfish, sturgeon fish such as non-salmonid disease is known to cause disease and cause great economic losses (Kahraman, 2013).

Although, Y. ruckeri can reproduce between $9-37^{\circ} \mathrm{C}$, the optimum breeding temperature was determined to be $20-25^{\circ} \mathrm{C}$ (Austin and Austin, 1987). Studies are mostly focused on disease prevention because of the costly treatment, labor demand, antibiotic use causing resistance to pathogenic and non-pathogenic microorganisms and threatening human and animal health in this case (Timur and Timur, 1985).

Since fish pathogens can transfer resistance genes to bacteria that cause disease in humans, their use is limited (Uluköy et al., 2013). The unconscious use of antibiotics in the treatment of bacterial diseases in aquaculture can lead to the development of resistant bacteria and may have negative effects on the environment, humans and other living things. However, the use of alternative methods is also important due to reasons such as the inability to vaccinate after the disease has occurred and the resistance of the agents to antibiotics (Hatha et al., 2005).

\section{Material and Methods}

\subsection{Supply of isolates}

This study was carried out with the approval of the Animal Experiments Local Ethics Committee of Van Yuzuncu Yil University, dated 07/09/2018 and numbered 64096. ATCC 29473 reference Y. ruckeri strain and $Y$. ruckeri isolated at different times were used in the study. All bacteria were incubated in TSA and WS media at $37^{\circ} \mathrm{C}$ for 24 hours. Typical colonies with morphological similarities were selected and identified. During the study, bacteria were stored at $-80{ }^{\circ} \mathrm{C}$ in $15 \%$ glycerol, $85 \%$ medium (Austin, 1999).

\subsection{Biochemical characterization}

Y. ruckeri cultures isolated on medium and Gram stained, catalase and oxidase tests were carried out. After $24 \mathrm{~h}$ incubation at $37{ }^{\circ} \mathrm{C}$ in TSA medium, bacteria adjusted to McFarland 0.5 optical density were inoculated into the capsules in the kit and left to incubate at $37^{\circ} \mathrm{C}$ for 24 hours. After incubation, the results were evaluated as positive and negative according to the Microgen company reading table. The results were matched with the Microgen website program and their biochemical identifications were performed (Gulaydin et al., 2018).

\subsection{Molecular characterization}

\subsubsection{DNA isolation}

Genomic DNA of bacteria was isolated with GeneJet Genomic DNA isolation kit for the molecular identification of the isolates according to the manufacturer's instructions. The purity of the isolated DNAs was measured with a nanospectrophotometer (Thermo) at $260 \mathrm{~nm}$ wavelength. Isolated DNAs were stored at $-20{ }^{\circ} \mathrm{C}$ during the study period (Önalan and Yavuz, 2019).

\subsubsection{Real-Time PCR}

Isolated DNAs were adjusted to $25 \mu 1$ total volume using Y. ruckeri specific Forward and Reverse primers (27f (5'-AGAGTTTGATCCTGGCTCAG-3') and 1492r (5'-GGTTACCTTGTTACGACTT-3') (Lane, 1991)), 2X SYBRGreen master mix, DNase-RNase free water. After, $95{ }^{\circ} \mathrm{C}$ for $10 \mathrm{~min}$ pre-denaturation in Real-Time PCR, denaturation at $94^{\circ} \mathrm{C}$ for $45 \mathrm{~s}$, binding at $55^{\circ} \mathrm{C}$ for $30 \mathrm{~s}$ and elongation at $72{ }^{\circ} \mathrm{C}$ for $45 \mathrm{~s}$ were completed in 45 cycles. As a final step, PCR was completed with a final extension at $72{ }^{\circ} \mathrm{C}$ for $7 \mathrm{~min}$. Non-template control tubes were used as negative controls. Samples giving sigmoidal curves were evaluated as positive in RotorGene Q 9000 software. As a result of sequence analysis to be performed with PCR amplicons, the identification and similarity rates of $Y$. ruckeri isolates used in the study were determined (Önalan and Arabaci, 2016). Real-Time PCR amplicons were sent for sequence analysis and nucleic acid sequences were blasted on the NCBI website and the similarity rates of the isolates were obtained.

\subsubsection{Spectrophotometric determination of the effects} of phytochemicals in liquid media

Moringa (M. oleifera) and Sorbus ( $S$. domestica) phytochemicals were commercially purchased in liquid form. The purchased plant extracts were diluted in different dilutions and applied in solid (for antibiogram test) and liquid (for spectrophotometric measurement) media. To determine the effects of phytochemicals and antibiotics on bacterial cultures to be used in the study, suspension solutions consisting of 10 groups were prepared (Table 1). In this study, untreated groups with bacteria will be used as negative control. The growth of the reference bacteria was measured in the Tryptic Soy Broth (TSB) as a positive control. Measurements were taken every 2 hours (Bayaz, 2014).

\subsubsection{Antibiogram test}

In the antibiogram test, $100 \mathrm{ul}$ Y. ruckeri suspensions were spread with drigaski on Müller-Hinton Agar (MHA) medium. The antibiotic discs (OX and ENR) were then placed symmetrically in Petri dishes. The media were incubated at $37{ }^{\circ} \mathrm{C}$ for 24 hours. The zone diameters formed after the incubation period were measured in $\mathrm{mm}$ with the help of a ruler. The results were compared with Antibiotic Zone Diameter Table (Akhlaghi and Sharifi-Yazdi, 2008). 


\section{Results}

\subsection{Microbiological results}

To isolate the bacteria, after the first planting in TSA and WS media, the bacteria were purified from single colonies selected according to colony morphology. Then, blood agar (BA) medium was carried out planting and hemolytic properties of the developing bacteria were determined (Figure 1).

Blood agar bacteria as a result of the tests performed Gram-negative, catalase positive, oxidase negative and were observed that they are mobile (Table 2).

Microgen's GNA+B ID system was used to determine the biochemical properties of Y. ruckeri isolates. According

Table 1. Groups created for spectrophotometric measurements.

\begin{tabular}{|c|c|}
\hline No & Group \\
\hline 1 & $10 \mathrm{~mL}$ TSB Control (10 mL TSB) \\
\hline 2 & $\begin{array}{l}10 \mathrm{~mL} \text { TSB }+50 \mu 1 \text { bacteria (Zero-reset } \\
\text { with group 1) }\end{array}$ \\
\hline 3 & $10 \mathrm{~mL}$ TSB $+400 \mu 1$ Moringa \\
\hline 4 & $\begin{array}{l}10 \mathrm{~mL} \text { TSB }+400 \mu 1 \text { Moringa }+50 \mu 1 \\
\text { bacteria (Zero-reset with group } 3 \text { ) }\end{array}$ \\
\hline 5 & $10 \mathrm{~mL}$ TSB $+400 \mu \mathrm{l}$ Sorbus \\
\hline 6 & $\begin{array}{l}10 \mathrm{~mL} \text { TSB }+400 \mu \mathrm{l} \text { sorbus }+50 \mu \mathrm{l} \\
\text { bacteria (Zero-reset with group } 5 \text { ) }\end{array}$ \\
\hline 7 & $\begin{array}{l}10 \mathrm{~mL} \text { TSB }+1-\mathrm{OX}+50 \mu 1 \text { bacteria (Zero- } \\
\text { reset with group 9) }\end{array}$ \\
\hline 8 & $\begin{array}{l}10 \mathrm{~mL} \text { TSB }+1-\mathrm{ENR}+50 \mu \mathrm{l} \text { bacteria } \\
\text { (Zero-reset with group } 10 \text { ) }\end{array}$ \\
\hline 9 & 10 mL TSB+1 Disk OX \\
\hline 10 & 10 mL TSB+1 Disk ENR \\
\hline
\end{tabular}

TSB: Tryptic soy agar, OX: Oxytetracycline, ENR: Enrofloxacin.

Table 2. Some microbiological test results of Y. ruckeri isolates.

\begin{tabular}{lcc}
\hline \multicolumn{1}{c}{ Testin adı } & $\begin{array}{c}\text { Y. ruckeri } \\
\text { reference strain }\end{array}$ & $\begin{array}{c}\text { Y. ruckeri } \\
\text { isolate }\end{array}$ \\
\hline Gram staining & $(-)$ & $(-)$ \\
Catalase & $(+)$ & $(+)$ \\
Oxidase & $(-)$ & $(-)$ \\
Movement & $(+)$ & $(+)$ \\
\hline
\end{tabular}

* (-): Negative, $(+)$ : Positive.
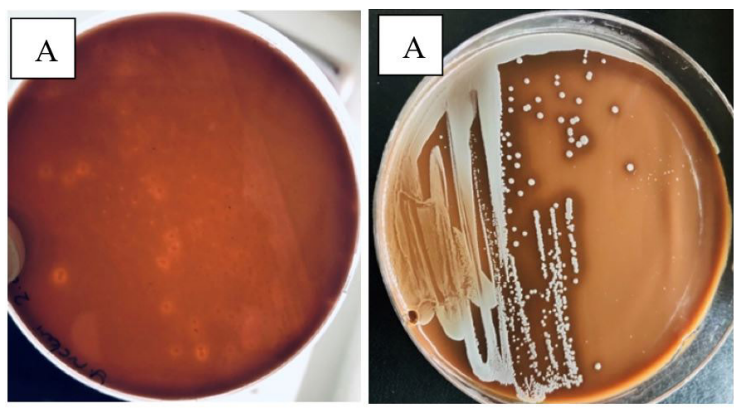

Figure 1. Image of Y. ruckeri isolates growing on blood agar medium (A) Y. ruckeri reference strain; (B) Y. ruckeri isolate).
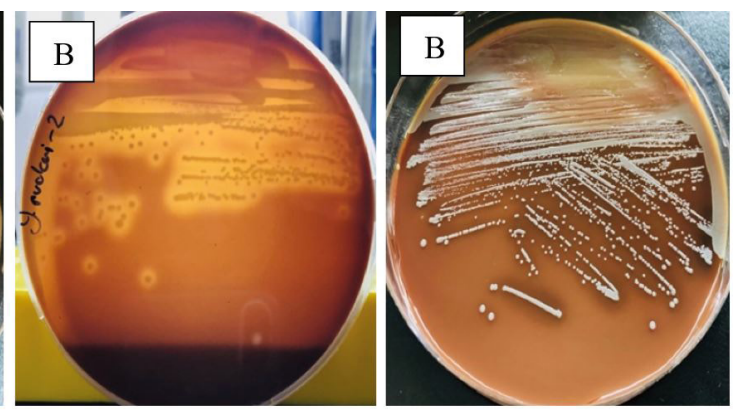

to color changes following bacterial incubation, biochemical test results (Table 3 ) are given below.

Biochemical test results were evaluated according to the color changes caused by the reaction between the reagents and the bacteria in the kit wells. By entering positive (+) and negative (-) results in the software of Microgen company, it was confirmed that $99.85 \%$ of the isolates were Y. ruckeri according to the results report obtained online. Also, there was no difference between the biochemical test results of 2 different $Y$. ruckeri isolates.

\subsection{Molecular characterization}

The identification of the bacteria used in the study with different methods and whether there were differences between the isolates were used. Molecular methods to perform this process using the molecular identification of bacteria for universal bacterial primers performed using Real-Time PCR results are given below (Figure 2).

According to the results of Real-Time PCR analysis, $Y$. ruckeri reference and isolate used in the study yielded sigmoidal curves and were positive. Samples used as negative controls (NTC and Master mix Control) were found to be negative with a straight line below the threshold value. After Real-Time PCR analysis, sequencing of the $16 \mathrm{~S}$ rRNA gene region was performed using PCR amplicons and primers $27 \mathrm{~F}-1492 \mathrm{R}$. The results of the sequence were confirmed to be $Y$. ruckeri in the gene bank by NCBI Blast application. 16S rRNA gene sequences of the bacteria used in the study are given below (Figure 3).

The sequence data and the data obtained after the blasting process was used in the CLC Main Workbench software to generate phylogenetic trees. The phylogenetic similarities of the isolates used in the study are given below (Figure 4). According to these results, Y. ruckeri isolates were similar with $99 \%$ similarity rate.

\subsection{Antibiogram test results}

In the antibiogram test, 100 bacteria were grown in MHA medium (25 mL/Petri). Moringa and Sorbus solutions were added to the empty discs in the same amount as the antibiotic (ENR and OX) disc ratios and $15 \mu 1$ empty discs. Zone diameters were calculated after a 24-hour incubation period at $37^{\circ} \mathrm{C}$. The antibiotic was evaluated within the limits specified in the Zone Diameter Table. 
Table 3. Biochemical test results of Y. ruckeri isolates.

\begin{tabular}{|c|c|c|c|c|c|}
\hline Test & Explanation & Result & Test & Explanation & Result \\
\hline INO & Acid from Inositol & + & TDA & Tryptophan Deaminase & - \\
\hline LYS & Lysine Decarboxylase & + & GEL & Gelatine Liquefaction & + \\
\hline ORN & Ornithine Decarboxylase & + & MAL & Malonate Utilization & - \\
\hline $\mathrm{H}_{2} \mathrm{~S}$ & Hydrogen Sulfide Production & - & SOR & Acid from Sorbitol & - \\
\hline GLU & Acid from Glucose & + & RHA & Acid from Rhamnose & - \\
\hline MAN & Acid from Mannitol & + & SUC & Acid from Sucrose & - \\
\hline XYL & Acid from Xylose & - & LAC & Acid from Lactose & - \\
\hline ONPG & O-Nitrophenyl- $\beta$-D-Galactopyranoside & + & ARA & Acid from Arabinose & - \\
\hline IND & Indole & - & ADO & Acid from Adonitol & - \\
\hline UR & Urea Hydrolysis & - & RAF & Acid from Raffinose & - \\
\hline VP & Voges Proskauer & - & SAL & Acid from Arabinose & - \\
\hline CIT & Citrate Utilization & + & $\mathrm{ARG}$ & Arginine Dihydrolase & - \\
\hline
\end{tabular}

* (-): Negative, (+): Positive.

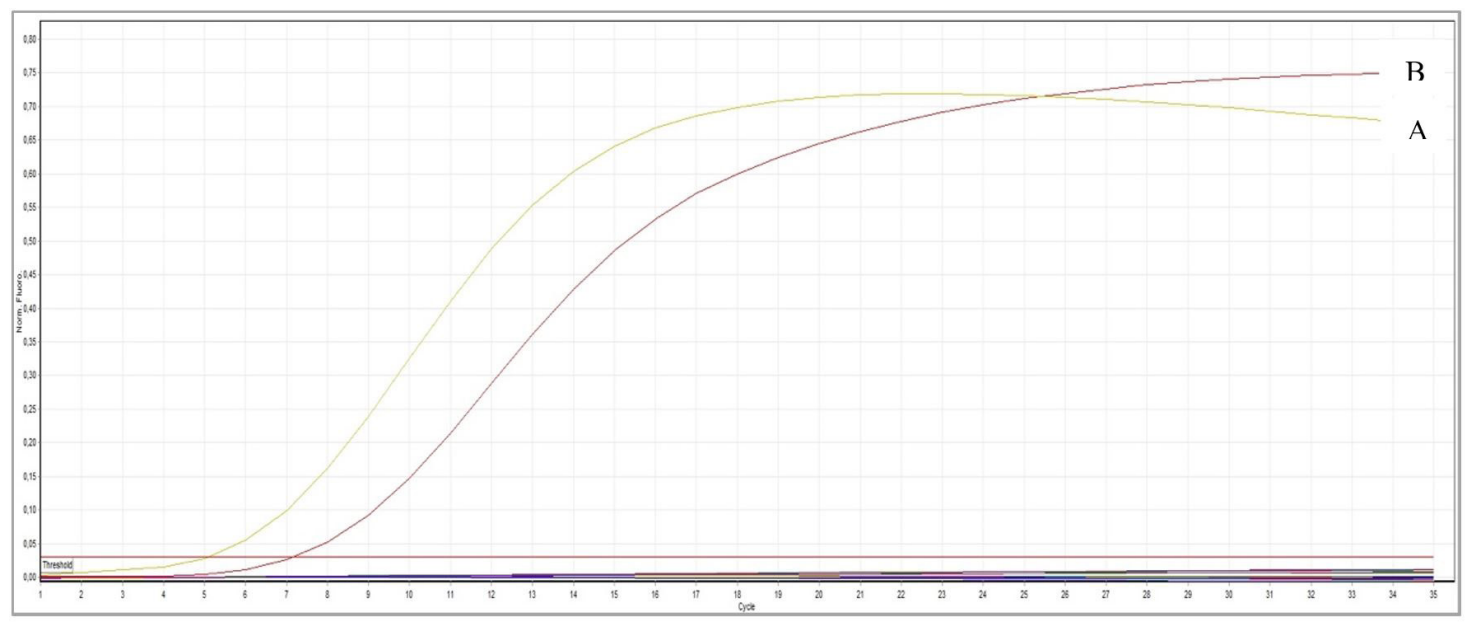

Figure 2. Real-Time PCR result of Y. ruckeri isolates (A) Y. ruckeri reference strain; (B) Y. ruckeri isolate).

ENR and OX antibiotics were found to have $24 \mathrm{~mm}$ zone diameter on MHA medium in the antibiogram test. In antibiotic Zone Diameter Table, this value was found to be resistant, while $M$. oleifera was $11 \mathrm{~mm}$ and $S$. domestica was $11 \mathrm{~mm}$. With these values, M. oleifera and $S$. domestica $(11,9 \mathrm{~mm})$ were found to be sensitive to ENR and OX (Figure 5).

\subsection{Spectrophotometric development results}

To investigate the effects of antibiotics and phytochemicals on the growth of $Y$. ruckeri isolates in liquid medium, their concentrations (OD) at $600 \mathrm{~nm}$ were measured with 10 groups. The graph obtained using spectrophotometric development values are given below (Figure 6).

Moringa and Sorbus extracts were found to have more effects on the liquid medium than the solid medium (antibiogram test). In themselves, Moringa extract was found to be more effective than Sorbus extract. In the antibiogram test, it was observed that the sensitive phytochemicals inhibited the growth of bacteria by $50 \%$, especially Moringa.

According to the obtained graph, it was observed that the bacterial growth in TSB medium was highest at $600 \mathrm{~nm}$ in the first 2 hour measurements, while the effect of OX and ENR antibiotics levels did not begin at the beginning compared to the control group. Bacterial growth was found to be slower (40-50\%) in Sorbus and Moringa groups. Bacterial growth was highest in the $\mathrm{TSB}+$ Yr group at the 14th and 16th hours, and the highest levels were observed at the 18th and 20th hours in the OX and ENR antibiotics groups.

\section{Discussion}

As in many other areas in the world, it is known that the use and effects of plants on fish in the fisheries sector are investigated (Yigitarslan et al., 2011). In a limited number of studies conducted to determine the possibilities of using plants and active substances in aquaculture, it was reported that plant extracts added to food and water improved feed consumption, feed utilization, growth and carcass quality (Şimşek et al., 2005; Immanuel et al., 2009).

Medicinal plant extracts have some antimicrobial effects on some bacterial and fungal species that have been studied for many years (Kivanç and Akgül, 1986). In recent years, some researches have been conducted on the use of medicinal plants as feed additive in general 


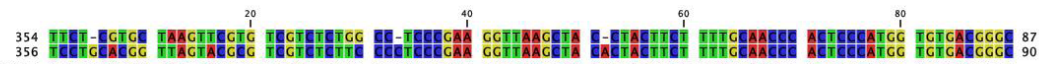

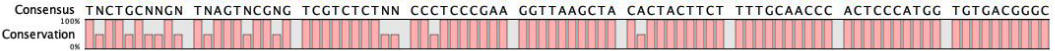

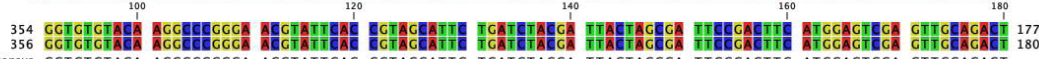

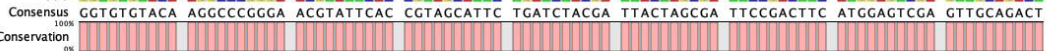

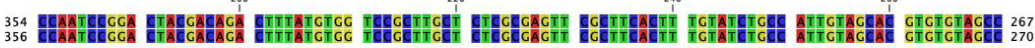

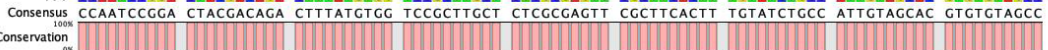

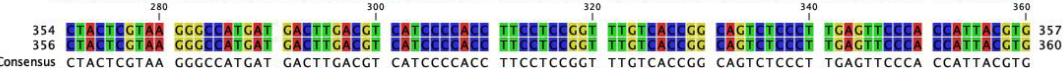

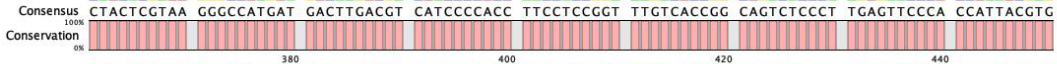

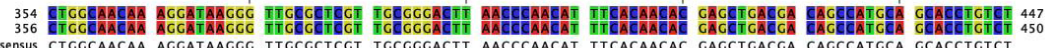

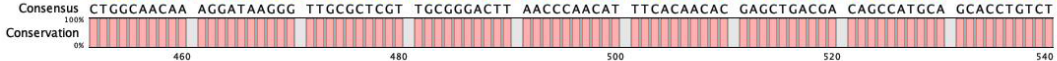

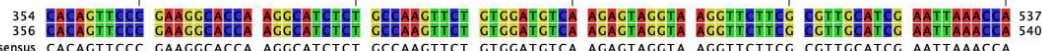

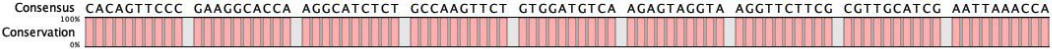

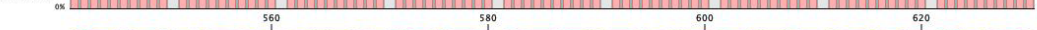

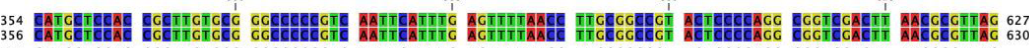
Consensus CATGCTCCAC CGCTTGTGCG GCCCCCCGTC AATTCATTTG AGTTTTAACC TTGCGGCCGT ACTCCCCCAGG CGGTCCACTT AACGCGTTAG

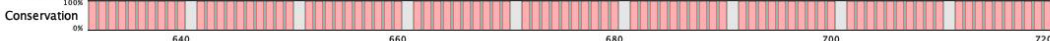

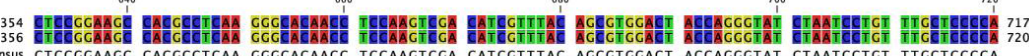

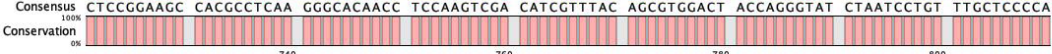

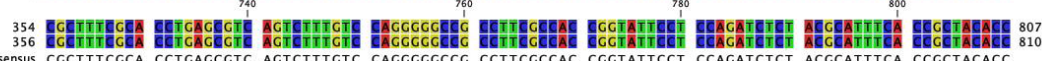

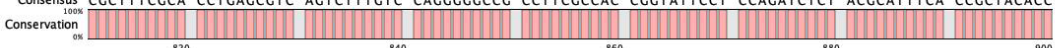

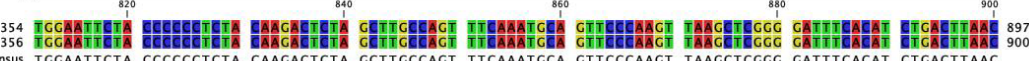

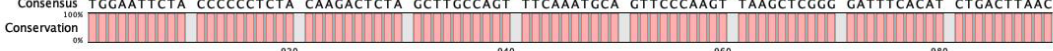

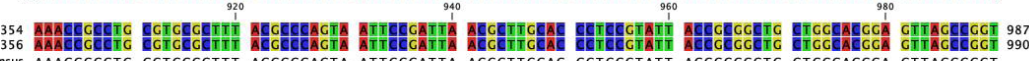

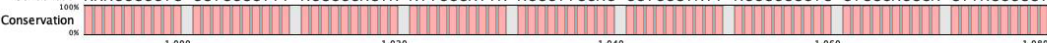

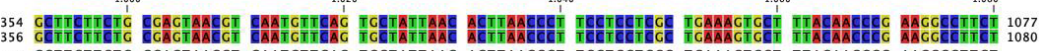

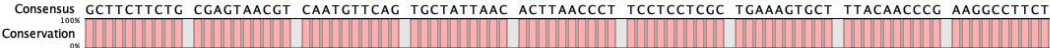

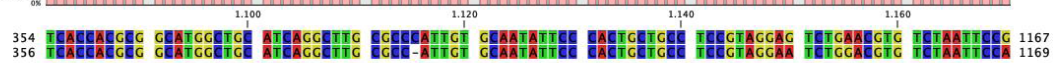
Consensus TCACCACCCG GCATGGCTCC ATCAGCCTTG CGCCCATTGT GCAATATTCC CACTCCTCCCC TCCGTAGGAN TCT GNACGTG TCTAATTCCN Conseration

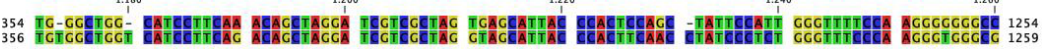

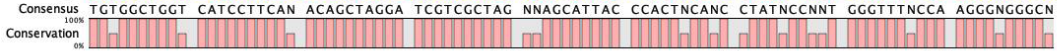

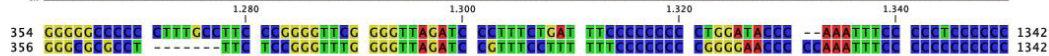

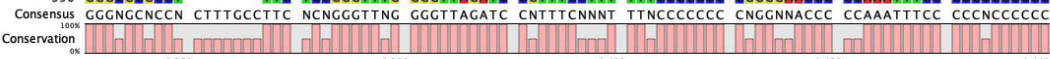

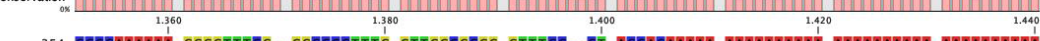

354
336

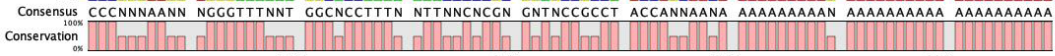

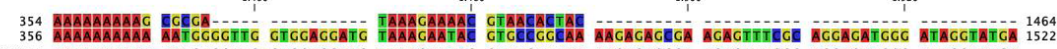
consenus aAAAAM

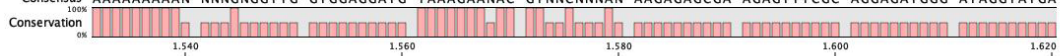

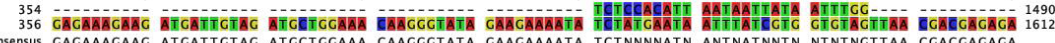
Consensus GAGAAAGAAG ATGATTGTAG ATGCTGGAAA CAAGGGTATA GAAGAAAATA TCTNNNNATN ANTNATNNTN NTNTNGTTAA CGACGAGAGA Conseratox

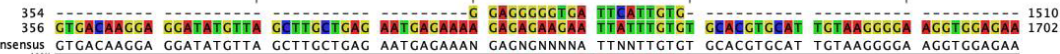

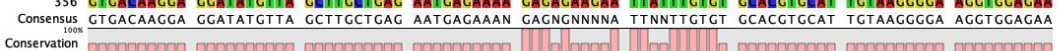
Conserestox

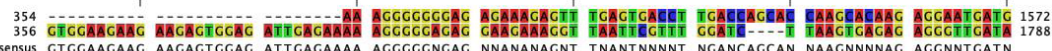

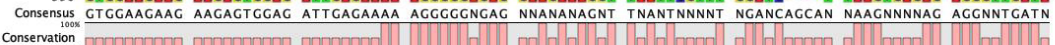

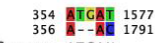

Consensus sion
Conservation
ox

Figure 3. 16S rRNA gene sequences of $Y$. ruckeri isolates used in the study (354: Y. ruckeri reference strain, 356: Y. ruckeri isolate). 


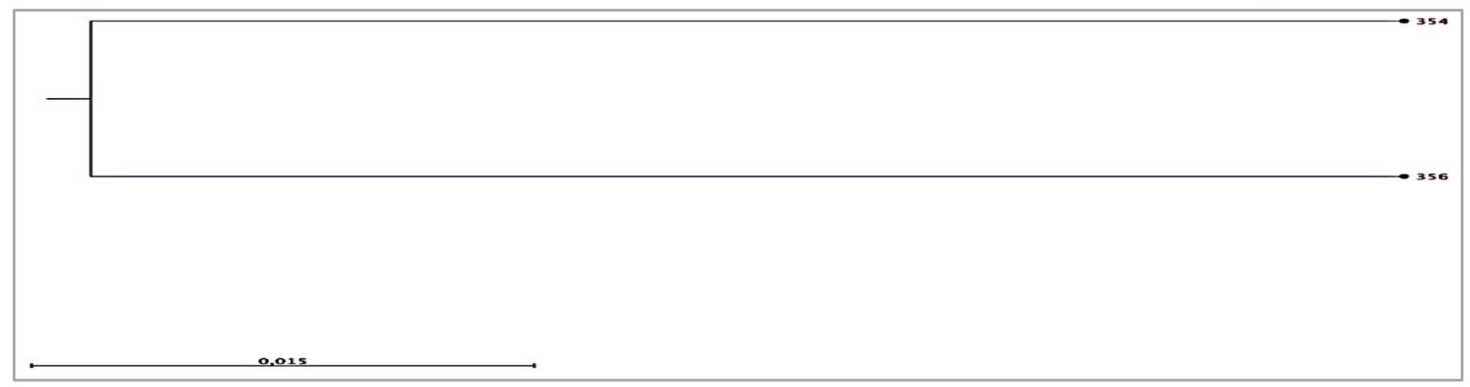

Figure 4. Phylogenetic similarity results of Y. ruckeri isolates used in the study (354: Y. Ruckeri reference strain, 356: Y. ruckeri isolate).

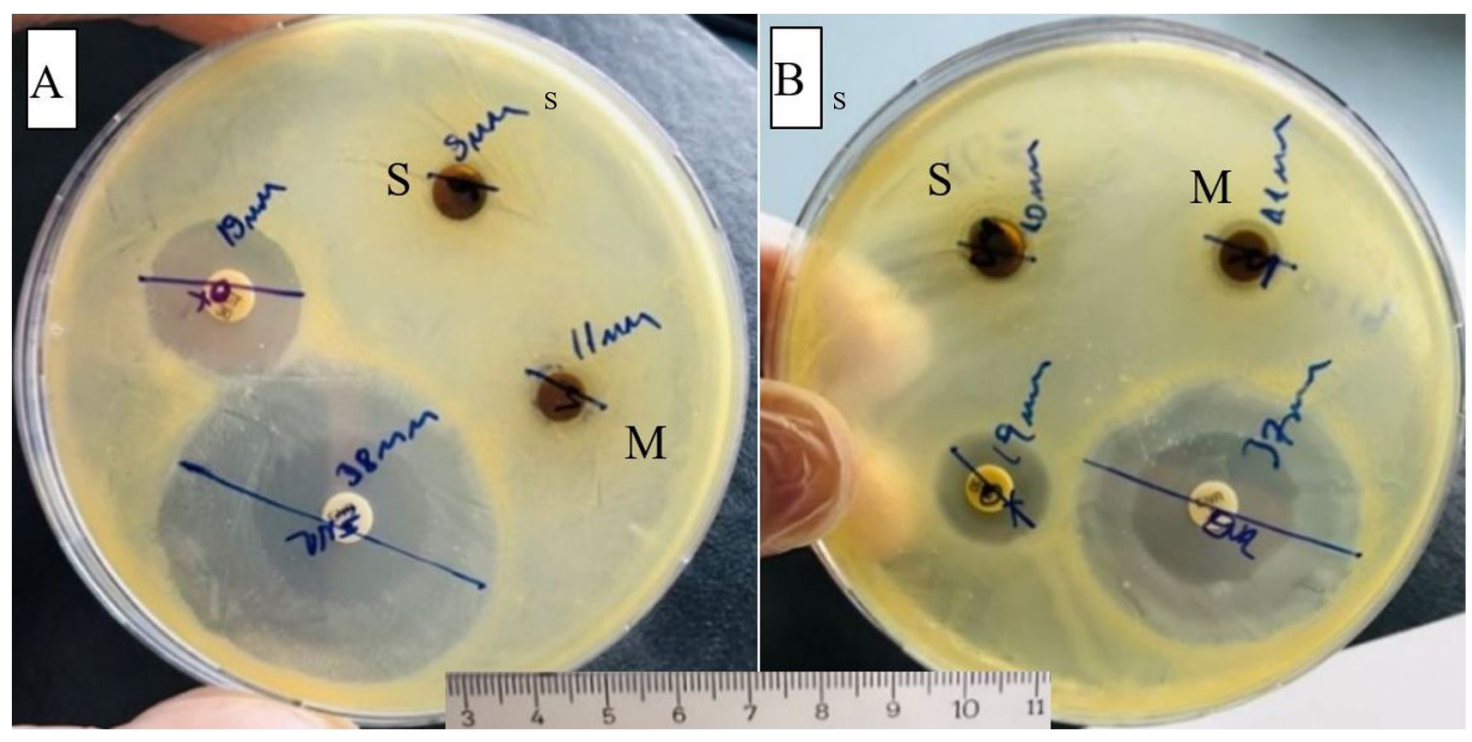

Figure 5. Antibiogram test results of antibiotics and phytochemicals used in the study (A) Y. ruckeri reference strain; (B) Y. ruckeri isolate, M: Moringa oleifera, S: Sorbus domestica).

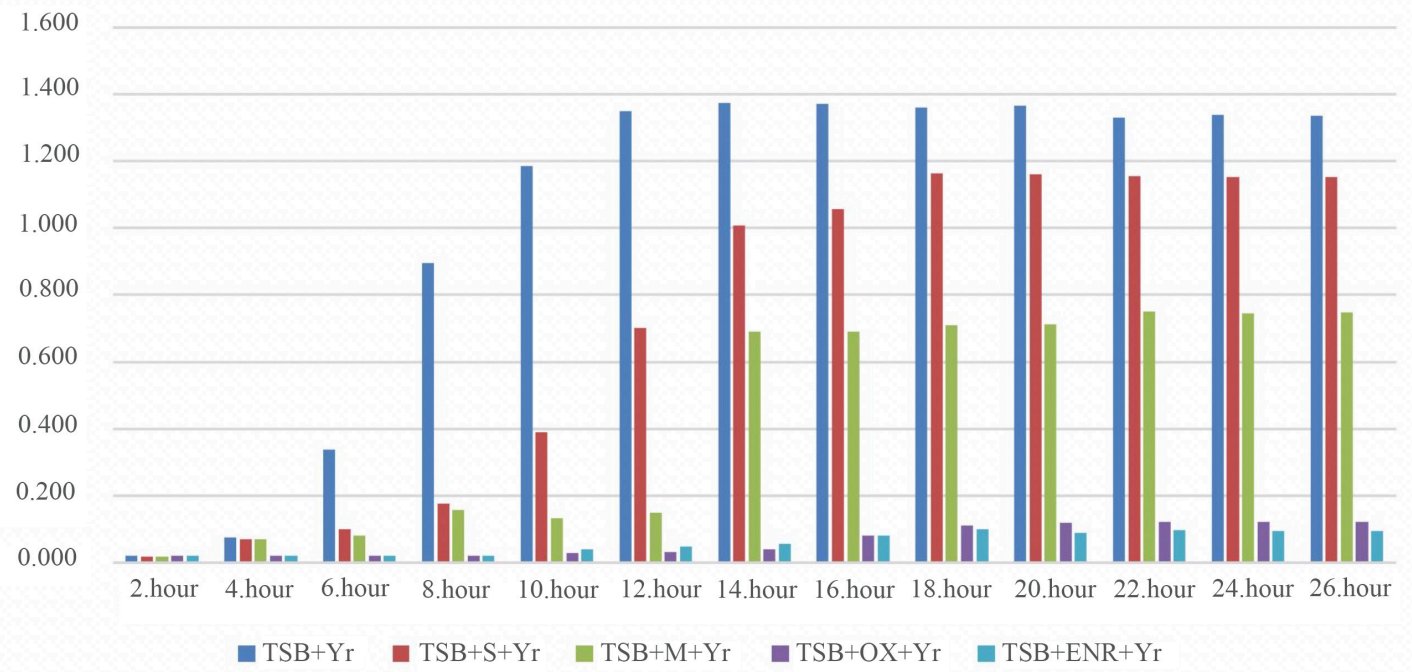

Figure 6. Spectrophotometric development rates of $Y$. ruckeri isolates in antibiotic and phytochemical supplemented medium ("TSB+Yr": Triptic Soy Broth + Y. ruckeri, "TSB+S+Yr": Triptic Soy Broth+Sorbus + Y. ruckeri, "TSB+M+Yr": Triptic Soy Broth+Moringa + Y. ruckeri, "TSB+OX+Yr": Triptic Soy Broth+Oxytetracycline + Y. ruckeri, "TSB+ENR+Yr": Triptic Soy Broth+Enrofloxacin + Y. ruckeri). 
animal and aquaculture production, increase in growth, positive results in feed evaluation and use as preventive products (Görmez, 2012). In addition to being easier to obtain and inexpensive, herbal products are preferred because some plants act against bacterial, viral, fungal and parasitic agents (Cihangir and Diler, 2016).

M. oleifera (Moringaceae) is a very valuable plant, distributed in many tropical and subtropical countries. It has a high nutritional value and an impressive range of medical uses. Different parts of this plant contain a profile of important minerals and are good sources of protein, vitamins, carotene, amino acids and various phenolic. In addition to its water treatment forces and high nutritional value, $M$. oleifera is very important for its medicinal value. Various parts of this plant, such as leaves, roots, seeds, bark, fruit, flowers and immature bark, serve as stimulating the heart and circulation. It has anti-diabetic, hepatoprotective, anti-bacterial and anti-fungal activities and is used especially for the treatment of different diseases in the native drug system in South Asia (Anwar et al., 2007). Medicinal plants and the essential oils obtained from them have anti-bacterial, anti-viral, anti-fungal, anti-inflammatory, antiseptic, antioxidant, anti-parasitic, anti-toxigenic and insecticidal properties have been reported to be effective on microorganisms resistant to antibiotics in the studies (Yigitarslan et al., 2011).

Y. ruckeri isolates used in this study were used in microbiological tests; In terms of gram staining, $Y$. ruckeri isolate was found to be Gram negative in the form of red-pink bacteria seen on microscope as a result of exposure to crystal violet, lugol alcohol and saffron. Similarly, some researchers have stated that Gram staining results are negative in their studies (Kubilay, 1997; Okka, 2009). In this study, oxidase reagent kit was poured onto sterile filter paper which was placed in a Petri box to determine the oxidase properties of the bacteria. Many studies conducted with $Y$. ruckeri have reported the same results (Tiravoglu-Demirtas, 2006). The catalase tests of the isolates used in the study were carried out by adding a colony with the aid of hydrogen peroxide which was poured a few drops on the slide. Foam catalase formed due to $\mathrm{O}_{2}$ deficit from the presence of catalase was observed as positive. It was reported by some researchers that the catalase test was performed with the same method and that the same results were obtained on Y. ruckeri (Korun et al., 2019). To determine the motility of the isolates, Y. ruckeri isolate which was applied on a drop of PBS dropping slide was examined under a microscope and the bacteria showed Glayding movement. Similarly, some researchers reported that they obtained similar results in their studies on the same factor (Koyun and Şeker, 2017). GNA+B (Microgen) kits were used to evaluate the isolates for biochemical tests. Y. ruckeri isolates in suspension were incubated at $37^{\circ} \mathrm{C}$ for 24 hours after inoculating the wells in the kit and then the results were evaluated as positive and negative according to the Microgen company reading table. The results were matched with Microgen web site program and it was concluded that $Y$. ruckeri was $99.85 \%$ in terms of biochemical identification. Biochemical properties and differences between bacteria are of great importance in microbiological studies. In-species differences of bacteria cause different results in biochemical reactions of the same bacteria (Önalan, 2019).

In the application of biochemical tests, many researchers have obtained different kits and methods. Some researchers have performed biochemical tests with API kits (Santos et al., 1993), some researchers from automated systems BD Phoenix ID (Muraleedharan et al., 2019) and some researchers VITEK (Arias et al., 2007; Crowley et al., 2012) reported that they investigated the biochemical properties of $Y$. ruckeri isolates by automated system. Recently, it has been reported by some researchers that the identification of $Y$. ruckeri with MALDI_TOF_MS, which is a new and widespread method in bacterial identification, is very high (Popovic et al., 2017). In addition to the many studies that carried out biochemical tests with different methods, many studies have also been reported by $Y$. ruckeri biochemical properties and differences using GNA+B (Microgen) kits used in this study and performed by manual system (Lutwyche et al., 1995; Gulaydin et al., 2018).

Although, morphological and biochemical tests can be used to identify and characterize bacteria, nowadays, they are the most sensitive method. These studies performed on DNA and RNA interactions and sequences are frequently used in microbiological studies to reveal identification differences. In this study, Real-Time PCR analysis was performed for the molecular identification of bacterial isolates. Universal primers (27F-1492R) specific to the $16 \mathrm{~S}$ rRNA gene, which are frequently used for identification in bacteria, were used for this purpose. PCR amplicons were confirmed from the gene bank after sequencing. Although, it has been reported by some researchers that the $16 \mathrm{~S} \mathrm{rRNA}$ gene is used for the identification of bacteria (Altun et al., 2013), some researchers used ompTS, gyrA, Yer, n-DNA and p57 gene in the PCR method for the test of molecular identification (Bastardo et al., 2011; Altun et al., 2013).

Comparisons of the phytochemicals used in the study with antibiotic discs were made with the antibiogram test. The antibiogram test of ENR and OX antibiotics showed a zone diameter of $24 \mathrm{~mm}$ in MHA medium. In the Antibiotic Zone Diameter Table, this value was found to be resistant, while $M$. oleifera was $11 \mathrm{~mm}$ and $S$. domestica was $11 \mathrm{~mm}$. With these values, M. oleifera and $S$. domestica $(11,9,8 \mathrm{~mm})$ were found to be sensitive to ENR and OX. In line with these results, antibiotics used were resistant to Y. ruckeri. It was observed that $M$. oleifera and $S$. domestica extracts were sensitive to antibiotics, when considering the dilution of liquid solution and concentration ratio 10 times, it was observed that the plant extracts to be prepared in the same manner as the antibiotic powder forms could have the same effect.

As a result of the spectrophotometric measurements evaluating the bacterial growth in the liquid medium, the control group showed the highest bacterial growth at $600 \mathrm{~nm}$ in the first 2 hour measurements while the effect of OX and ENR antibiotics levels did not begin at 
the beginning of the control group. Bacterial growth was found to be slower in Sorbus and Moringa groups. Bacterial growth was highest in the TSB $+\operatorname{Yr}(Y r$ : Y. ruckeri) group at the 14th and 16th hours, and the highest levels were observed at the 18th and 20th hours in the OX and ENR antibiotics groups. In previous studies with Y. ruckeri, OX and ENR were reported to be resistant to bacteria in the antibiogram test (Akhlaghi and Sharifi-Yazdi, 2008; Bastardo et al., 2011). Because of their potential to be an alternative to chemical preservatives and antibiotics against fish pathogens, many researches have been conducted on the antibacterial effects of plant essential oils (Chiarello, 1995; Metin et al., 2017). In recent years, inadequate drugs and therapeutically effective substances, which are synthetic against bacterial disease agents, have led to studies on the use of different treatment methods (Toroglu and Çenet, 2006). In previous studies, it has been reported that sulfonamides and OXs are resistant to Y. ruckeri (Post, 1987). It was observed that the effects of M. oleifera and $S$. domestica extracts against the bacteria in the liquid medium (spectrophotometric test) were higher than the effects on the solid medium (antibiogram test). In themselves, Moringa extract was found to be more effective than Sorbus extract. In the antibiogram test, it was observed that the phytochemicals, which are susceptible, affect the growth of bacteria, especially Moringa, at a rate of $50 \%$.

As a result, it was observed that the isolates formed Gram negative, catalase positive, oxidase negative, mobile and typical Y. ruckeri colonies. After the biochemical tests performed with Microgen ID panel, 99.85\% similarity was determined. The isolates were $100 \%$ overlapping with the 16S rRNA gene region after sequence analysis, and 99\% of the isolates were similar in phylogenetic analysis. After the antibiogram test, it was observed that ENR and OX antibiotics were resistant to Y. ruckeri, but the effects of phytochemicals were less on solid medium. As a result of measurements carried out spectrophotometrically to evaluate the effects of bacterial growth on TSB medium, phytochemicals inhibited the growth of bacteria by $40-50 \%$. As the importance of antibiotic resistance is increasing day by day, we believe that the plants that are more economical and alternative to antibiotic use will give positive results in the treatment.

\section{Acknowledgements}

This study was carried out by Van Yuzuncu Yil University, Scientific Research Projects Coordination Unit (Master thesis) within the scope of FBA-2018-6886 project. This article was produced from Mustafa ÇEVIK's Master's Thesis under the consultancy of Şükrü Önalan.

\section{References}

AKHLAGHI, M. and SHARIFI-YAZDI, H., 2008. Detection and identification of virulent Yersinia ruckeri: the causative agent of enteric redmouth disease in rainbow trout (Oncorhynchus mykiss) cultured in Fars province, Iran. Majallah-i Tahqiqat- $i$ Dampizishki-i Iran, vol. 9, no. 4, pp. 347-352.

ALTUN, S., ONUK, E.E., CIFTCI, A., BÜYÜKEKIZ, A.G. and DUMAN, M., 2013. Phenotypic, genotypic characterization and antimicrobial susceptibility determination of Lactococcus garvieae strains. Kafkas Üniversitesi Veteriner Fakültesi Dergisi, vol. 19, no. 3 , pp. $375-381$

ANWAR, F., LATIF, S., ASHRAF, M. and GILANI, A.H., 2007. Moringa oleifera: a food plant with multiple medicinal uses. Phytotherapy research: PTR, vol. 21, no. 1, pp. 17-25. http:// dx.doi.org/10.1002/ptr.2023. PMid:17089328.

ARIAS, C.R., OLIVARES-FUSTER, O., HAYDEN, K., SHOEMAKER, C.A., GRIZZLE, J.M. and KLESIUS, P.H., 2007. First report of Yersinia ruckeri biotype 2 in the USA. Journal of Aquatic Animal Health, vol. 19, no. 1, pp. 35-40. http://dx.doi. org/10.1577/H06-011.1. PMid:18236630.

AUSTIN, B. and AUSTIN, D.A., 1987. Bacterial fish pathogens: disease in farmed and wild fish. Chichester: Paraxis publishing

AUSTIN, B., 1999. Emerging bacterial fish pathogens. Bulletin of the European Association of Fish Pathologists, vol. 19, no. 6, pp. 231-234.

BASTARDO, A., SIERRALTA, V., LEÓN, J., RAVELO, C. and ROMALDE, J.L., 2011. Phenotypical and genetic characterization of Yersinia ruckeri strains isolated from recent outbreaks in farmed rainbow trout (Oncorhynchus mykiss) (Walbaum) in Peru. Aquaculture (Amsterdam, Netherlands), vol. 317, no. 1-4, pp. 229-232. http://dx.doi.org/10.1016/j.aquaculture.2011.03.040.

BAYAZ, M., 2014. Essential oils: antimicrobial, antioxidant and antimutagenic activities. Academic Food Journal, vol. 12, no. 3, pp. 45-53.

CHIARELLO, A.G., 1995. Density and habitat use of primates at an Atlantic Forest Reserve of Southeastern Brazhji. Revista Brasileira de Biologia, vol. 55, no. 1, pp. 105-110. PMid:7569145.

CIHANGIR, E. and DILER, İ., 2016. The effect of thyme (Origanum vulgare) essential oil added to juvenile and juvenile rainbow trout (Oncorhynchus mykiss) feed on growth performance and feed efficiency. Süleyman Demirel University Journal of Ĕgirdir Fisheries Faculty, vol. 12, no. 2, pp. 86-96.

CROWLEY, E., BIRD, P., FISHER, K., GOETZ, K., BOYLE, M., BENZINGER JUNIOR, M.J., JUENGER, M., AGIN, J., GOINS, D. and JOHNSON, R., 2012. Evaluation of the VITEK 2 Gramnegative (GN) microbial identification test card: collaborative study. Journal of AOAC International, vol. 95, no. 3, pp. 778-785. http://dx.doi.org/10.5740/jaoacint.CS2011_17. PMid:22816270.

ERGÖNÜL, M.B., YAVUZCAN, H. and ALTINDAG, A., 2012. Fish Health and the Use of Immunostimulants. The Journal of Fisheries Science, vol. 6, no. 3, pp. 188.

GÖRMEZ, O., 2012. Antifungal activity of essential oils of some medicinal plants against saprolegnia species. Isparta: Graduate School of Natural and Applied Sciences, Süleyman Demirel University, 93 p. Master dissertation in Aquaculture.

GULAYDIN, O., ÖZTURK, C., ÖNALAN, Ş., KARAPINAR, Z., ARABACI, M., EKIN, I.H. and ILHAN, F., 2018. The investigation of the presence of some bacterial and viral agents in pearl mullet (Chalcalburnus tarichii, Pallas 1811) by real-time PCR and the histopathological examination. Fresenius Environmental Bulletin, vol. 27 , no. 12 , pp. 8286-8296. 
HATHA, M., VIVEKANANDHAN, A.A., JULIE JOICE, G. and CHRISTOL, 2005. Antibiotic resistance pattern of motile aeromonads from farm raised fresh water fish. International Journal of Food Microbiology, vol. 98, no. 2, pp. 131-134. http:// dx.doi.org/10.1016/j.ijfoodmicro.2004.05.017. PMid:15747443.

IMMANUEL, G., UMA, R.P., IYAPPARAJ, P., CITARASU, T., PUNITHA PETER, S.M., MICHAEL BABU, M. and PALAVESAM, A., 2009. Yemary medicinal plant extracts improve growth, immune activity and survival of tilapia Oreochromis mossambicus. Journal of Fish Biology, vol. 74, no. 7, pp. 1462-1475. http:// dx.doi.org/10.1111/j.1095-8649.2009.02212.x. PMid:20735646.

KAHRAMAN, UC., 2013. A new way to prevent yersiniosis: live vaccine. Turkey: Institute of Science and Technology, Karadeniz Technical University. 61 p. Master Dissertation in Fish diseases.

KIVANÇ, M. and AKGÜL, A., 1986. Antibacterial Activities of Essential Oils from Turkish Species and Citrus. Flavour and Fragrance Journal, vol. 1, no. 4-5, pp. 175-179. http://dx.doi. org/10.1002/ffj.2730010409.

KORUN, J., OKUDAN, E.Ş., YARDIMCI, R.E., TIMUR, G., ULUTAŞ, A., GÖKOĞLU, M., ÇELIK, Y.S. and BALCI, B.A., 2019. Investigation of antibacterial activities of ethanol and methanol extracts of some marine algae species on Yersinia ruckeri. Kocatepe Veterinary Journal, vol. 12, no. 3, pp. 1-1. http://dx.doi.org/10.30607/kvj.522959.

KOYUN, M. and ŞEKER, E., 2017. Investigation of bacterial flora in the gills of rainbow trout (Oncorhynchus mykiss Walbaum, 1792) cultivated in Kertan dam lake pertek region (5th Region). Firat University Journal of Science, vol. 29, no. 1, pp. 21-25.

KUBİLAY, A., 1997. A research on the production and detection of Antibodies Against Pathogen Bacteria Yersinia ruckeri in rainbow trout (Oncorhynchus Mykiss). Isparta: Süleyman Demirel University. $\mathrm{PhD}$ dissertation.

LANE, D.J., 1991. 16S/23S rRNA sequencing. In: E. STACKEBRANDT and M. GOODFELLOW, eds. Nucleic acid techniques in bacterial systematics. Chichester: John Wiley and Sons, pp. 115-175.

LUTWYCHE, P., EXNER, M.M., HANCOCK, R.E. and TRUST, T.J., 1995. A conserved Aeromonas salmonicida porin provides protective immunity to rainbow trout. Infection and Immunity, vol. 63, no. 8, pp. 3137-3142. http://dx.doi.org/10.1128/IAI.63.8.31373142.1995. PMid:7622241.

METIN, S., DİDINEN, B.I., MERCIMEK, E.B. and ERSOY, A.T., 2017. Antibacterial activity of some bacterial essential oils against some bacterial fish pathogens. Yunus Arastirma Bülteni, vol. 1, pp. 59-69.

MURALEEDHARAN, C., TALREJA, D., KANWAR, M., KUMAR, A. and WALİA, S.K., 2019. Occurrence of extended-spectrum $\beta$-lactamase-producing bacteria in urban Clinton River habitat. Journal of Global Antimicrobial Resistance, vol. 16, pp. 225-235. http://dx.doi.org/10.1016/j.jgar.2018.10.007. PMid:30316964.

NAYLOR, R.L., GOLDBURG, R.J., PRIMAVERA, J.H., KAUTSKY, N., BEVERIDGE, M.C.M., CLAY, J., FOLKE, C., LUBCHENCO, J., MOONEY, H. and TROELL, M., 2000. Effect of Aquaculture on World Fish Supplies. Nature, vol. 405, no. 6790, pp. 1017-1024. http://dx.doi.org/10.1038/35016500. PMid:10890435.

OKKA, S., 2009. Investigation of the presence of Yersinia ruckeri in trout farms in Denizli region. Aydın: Adnan Menderes University. $82 \mathrm{p}$. Master dissertation in microbiolgy.
ÖNALAN, Ş. and ARABACI, M., 2016. Determination of phenotypic, serotypic and genotypic differences of Lactococcus garvieae isolates obtained from rainbow trout farms in Van, Bitlis, Muş and Hakkari provinces. Turkey: Institute of Science, Van Yüzüncü Y1l University. 151 p. PhD dissertation in fish diseases.

ÖNALAN, Ş. and YAVUZ, H.İ., 2019. Spectrophotometric determination of developmental differences of Lactococcus garvieae isolates in nanoparticle containing media. Menba Journal of Fisheries Faculty, vol. 5, no. 1, pp. 6-15.

ÖNALAN, Ş., 2019. Expression Differences of Stress and Immunity Genes in Rainbow Trout (Oncorhynchus mykiss, Walbaum 1792) with Different Bacterial Fish Diseases. Israeli Journal of Aquaculture - Bamidgeh, vol. 71, pp. 1597.

PILARSKI, F., ROSSINI, A.J. and CECCARELLI, P.S., 2008. Isolation and characterization of Flavobacterium columnare (Bernardet et al. 2002) from four tropical fish species in Brazil. Brazilian Journal of Biology $=$ Revista Brasileira de Biologia, vol. 68, no. 2, pp. 409-414. http://dx.doi.org/10.1590/S151969842008000200025. PMid:18660972.

POPOVIC, N.T., KAZAZIC, S.P., STRUNJAK-PEROVIÇ, I. and COZ-RAKOVAC, R., 2017. Differentiation of Environmental Aquatic Bacterial İsolates By MALDI-TOF MS. Environmental Research, vol. 152, pp. 7-16. http://dx.doi.org/10.1016/j. envres.2016.09.020. PMid:27741451.

POST, G. 1987. Enteric redmouth disease (Yersiniosis). Textbook of fish health. Neptune City: THF Publications.

SANTOS, Y., ROMALDE, J.L., BANDIN, I., MAGARINOS, B., NUNEZ, S., BARJA, J.L. and TORANZO, A.E., 1993. Usefulness of the API-20E system for the identification of bacterial fish pathogens. Aquaculture (Amsterdam, Netherlands), vol. 116, no. 2-3, pp. 111-120. http://dx.doi.org/10.1016/0044-8486(93)90002-G.

ŞİMŞEK, Ü.G., GÜLER, T., ÇIFTÇİ, M., ERTAŞ, O.N. and DALKILIÇ, B., 2005. Effect of essential oil mixture (oregano, clove and anise) on live weight, carcass and sensory properties of broilers. Van Veterinary Journal, vol. 16, no. 2, pp. 1-5.

TIMUR, G. and TIMUR, M., 1985. A study on bacterial hemorrhagic septicemia causing high mortality in Egirdir lake sudak (Stizostedion lucioperca 1. 1758). Veterinary Journal of Ankara University, vol. 32, pp. 33-41.

TIMUR, M. and TIMUR, G., 2003. Fish diseases. Istanbul: Istanbul University Publications.

TIRAVOGLU-DEMIRTAS, Y., 2006. Comparative investigation of immune strength of monovalent and polyvalent vaccines prepared from y. ruckeri serotype $i$ and field strains against enteric red crescent disease in rainbow trout. Aydın: Adnan Menderes University. 84 p. PhD Dissertation in Microbiology.

TOROGLU, S. and ÇENET, M., 2006. Methods of determination of antimicrobial activities and usage areas of some plants used for therapeutic purposes, Kahramanmaraş Sütçü İmam University. Journal of Engineering Sciences, vol. 9, no. 2, pp. 12-20.

ULUKOY, G., BABA, E. and SAYIN, Z., 2013. In vitro antibacterial activity of fungal and plant extracts on Listonella anguillarum and Y. ruckeri fish pathogens. Journal of Fisheries, vol. 28, no. 2, pp. 119-134.

YIGITARSLAN, K.D., AZDURAL, K., YAVUZ, U., TURAN, F., 2011. Phytotherapy applications in trout. Türk bilimsel derlemeler dergisi, vol. 4, no. 1, pp. 63-68. 